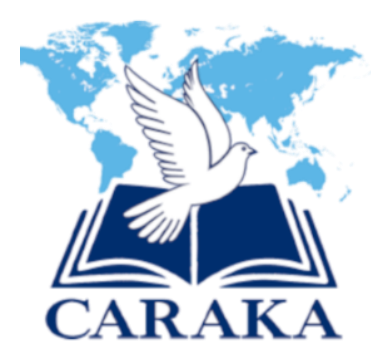

\title{
PANGGILAN TIMOTIUS MENURUT 2 TIMOTIUS 2:2 DAN IMPLIKASINYA BAGI KOMPETENSI GURU PENDIDIKAN AGAMA KRISTEN
}

\author{
Marthen Mau \\ Sekolah Tinggi Teologi Injili Arastamar Ngabang \\ marthenluthermau@gmail.com
}

\begin{abstract}
Timothy receive God's calling through Paul for pastoral ministry in Ephesus. Because there was no minister in that church. In 2 Timothy 2:2 Paul Gave assignments to Timothy to entrust the teachings he got from Paul to the faithful people who are able to teach the congregation. In the present time, the Christian religion teacher are given trust to hold the spiritual formation for student in the formal education institution. The religion teacher are given the task to hold the spiritual formation of the student as a form of implementing their competence of religion teacher are pedagody, personality, social, professional, and spiritual. This research is a qualitative research by applying the historical of grammatical method or exegetical methods on the text 2 Timothy 2: 2. Based on the exegetical method, it can be concluded that Christian religion teachers should be trustworthy, capable of teaching, dare to rebuke the wrongs, have loyalty, have integrity, and have spiritual qualities.
\end{abstract}

Keywords: Calling Timothy; 2 Timothy 2:2; Teacher competences

\begin{abstract}
Abstrak
Timotius menerima panggilan Tuhan melalui Paulus untuk pelayanan pengembalaan di Efesus. Oleh karena saat itu di jemaat Efesus belum ada pelayan Tuhan. Menurut 2 Timotius 2:2 Paulus memberikan tugas kepada Timotius untuk memberikan kepercayaan kepada orangorang yang dapat dipercayai dan sanggup mengajar orang lain di jemaat Efesus. Pada masa sekarang guru pendidikan agama Kristen menerima kepercayaan untuk melaksanakan pembinaan rohani peserta didik Kristen di lembaga pendidikan formal. Guru pendidikan agama Kristen diberikan tugas untuk melaksanakan pembinaan kerohanian kepada peserta didik sebagai bentuk mengimplementasikan kompetensi-kompetensi yang dimilikinya. Kompetensi yang dimiliki oleh guru pendidikan agama Kristen adalah pedagogik, kepribadian, sosial, profesional, dan spiritual. Penelitian ini merupakan penelitian kualitatif dengan menerapkan tipe metode historikal gramatikal atau eksegesis pada teks 2 Timotius 2:2. Berdasarkan metode eksegesis dapat disimpulkan bahwa guru pendidikan agama Kristen dapat dipercayai, cakap mengajar, berani untuk menegur yang salah, memiliki kesetiaan, memiliki integritas, dan memiliki kualitas rohani.
\end{abstract}

Kata Kunci: Panggilan Timotius; 2 Timotius 2:2; Kompetensi guru 


\section{PENDAHULUAN}

Surat 2 Timotius merupakan salah satu surat pastoral atau pengembalaan. Penulis surat 2 Timotius adalah rasul Paulus dan ditujukan kepada Timotius. Pada waktu itu Timotius menjadi seorang gembala sidang di jemaat Efesus. Jemaat Efesus merupakan anggota jemaat terbesar di Asia Kecil, sehingga perlu dibutuhkan seorang pelayan Tuhan yang memiliki kapabilitas dan loyalitas dalam pengabdiannya. Dalam surat 2 Timotius menarasikan tentang kedisiplinan umat untuk persekutuan dengan Kristus Yesus. Surat 2 Timotius merupakan surat wasiat kepada gereja Tuhan yang berdomisili di kota Efesus.

Saat Paulus dipenjarakan di penjara Roma; sebelum meninggal dunia ia mengirimkan pesan kepada jemaat di Efesus melalui Timotius. Pernyataan Eusebius dalam John R. W. Stott menyatakan bahwa:

Paulus dijatuhi hukuman mati dan kemudian dipenggal kepalanya (sebagaimana perlakuan yang seharusnya terhadap seorang warga negara Roma) di jalan Ostia, kirakira $5 \mathrm{~km}$ di luar kota. Paulus dan Petrus dibunuh pada saat yang sama. Meskipun Paulus dipenggal kepalanya tetapi Petrus (atas permintaannya sendiri) disalibkan dengan kepala di bawah. ${ }^{1}$

Kematian karena dipenggal kepala, disalibkan kepala ke atas atau ke bawah, dan di bunuh dengan cara yang lain oleh sebab memberitakan Injil Yesus Kristus merupakan kematian yang membawa kemuliaan bagi nama Kristus Yesus.

Pada saat Paulus menulis surat kepada Timotius, karena orang-orang Efesus menyeleweng dari kebenaran dan sibuk mengajarkan dongeng dan silsila. Orang Efesus tidak mengajarkan tertib hidup yang benar tentang keselamatan dalam iman kepada Kristus Yesus. ${ }^{2}$ Nasihat yang diberikan tidak didasarkan pada kasih yang timbul dari hati yang suci dan murni. Karena itu, melalui suratnyanya, Paulus menasihati Timotius supaya orang-orang tertentu tidak mengajarkan ajaran lain atau ajaran sesat. Tujuan Paulus menulis surat kepada Timotius adalah untuk mendorong Timotius supaya tetap mempertahankan kemurnian Injil dan standarnya yang kudus dari pencemaran oleh guru palsu dan untuk memberikan pengarahan mengenai berbagai urusan dan persoalan gereja di Efesus. ${ }^{3}$ Pengajaran yang harus disampaikan oleh Timotius dalam keadaan baik maupun maupun sebaliknya.

Waktunya yakni pengajaran berita Injil Yesus Kristus tanpa berhenti. Demikian pula, guru pendidikan agama Kristen dipanggil oleh Kristus Yesus dalam mengabdikan diri di lembaga pendidikan formal untuk melakukan pembinaan rohani kepada peserta didik Kristen.

\footnotetext{
${ }^{1}$ John R W Stott, 2 Timotius (Jakarta: Yayasan Bina Kasih OMF, 1997), 15.

2 Trisno Kurniadi, "Penguasaan Diri Hamba Tuhan Dalam Pelayanan Kajian Eksegetikal 2 Timotius 4:1 8," Manna Rafflesia 3, no. 2 (2017): 131-156.

${ }^{3}$ Maria Rukku and Daniel Ronda, "Pemimpin Yang Memiliki Integritas Menurut 2 Timotius Pasal 2," Jurnal Jaffray 9, no. 1 (2011): 25.
} 
Sesungguhnya, pembinaan rohani adalah pembinaan hati, yakni pembinaan yang bersifat menyeluruh dapat berlangsung apabila dilaksanakan secara terus-menerus oleh semua pihak dengan mengembangkan daya-daya kemampuan jasmani dan rohani peserta didik Kristen. ${ }^{4}$ Pendapat ini dapat dipahami bahwa guru pendidikan agama Kristen merupakan salah satu pihak yang berperan penting mendewasakan kerohanian peserta didik Kristen melalui pembinaan rohani. Jadi, pembinaan rohani merupakan suatu upaya pembinaan yang dilakukan oleh guru pendidikan agama Kristen kepada peserta didik supaya dapat memperbaiki dan memperbarui tingkah lakunya berdasarkan firman Tuhan agar memiliki kepribadian yang sehat, akhlak yang terpuji, dan bertanggung jawab dalam menjalani kehidupannya sehari-hari.

Pendidikan dan pembinaan rohani peserta didik Kristen harus mencapai tujuan pendidikan nasional yang diharapkan. Ihsan mengutip penjelasan pendidikan nasional dalam bukunya menyatakan:

Pendidikan nasional bertujuan meningkatkan ketaqwaan Tuhan Yang Maha Esa, kecerdasan dan keterampilan, mempertinggi budi pekerti, memperkuat kepribadian dan mempertebal semangat kebangsaan dan cinta tanah air agar dapat menumbuhkan manusia-manusia pembangunan yang dapat membangun dirinya sendiri serta bersamasama bertanggungjawab atas pembangunan bangsa. ${ }^{5}$

Pembinaan kerohanian peserta didik Kristen dapat tercapai dengan baik apabila peserta didik meningkatkan kepercayaan kepada Tuhan Yesus Kristus secara berkesinambungan. Karena itu, peran penting pada semua unsur pendidikan, seperti Yudo Wibowo menyatakan bahwa pemerintah pusat maupun daerah dapat mengarahkan, membimbing, membantu, dan mengawasi penyelenggaraan pendidikan sesuai dengan peraturan perundang-undangan yang berlaku. ${ }^{6}$ Pemerintah perlu memberikan layanan dan kemudahan, menjamin terselenggaranya pendidikan yang bermutu bagi setiap warga negara, serta menyediakan dana guna terselenggaranya pendidikan, termasuk pembinaan kerohanian peserta didik Kristen.

Guru pendidikan agama Kristen secara langsung berhadapan dengan peserta didik perlu memiliki kompetensi dan kualifikasi yang mantap. Karena itu, Barlow menyatakan bahwa kemampuan seorang guru dalam melaksanakan kewajiban-kewajibannya secara bertanggung jawab dan layak. ${ }^{7}$ Guru pendidikan agama Kristen yang mampu melaksanakan profesinya disebut sebagai guru yang kompeten di bidangnya secara profesional. Karena itu,

\footnotetext{
${ }^{4}$ Firdaus Firdaus, "Upaya Pembinaan Rohani Dan Mental," Al-Adyan: Jurnal Studi Lintas Agama 9, no. 1 (2014): 119-142.

${ }^{5}$ H Fuad Ihsan, Dasar-Dasar Kependidikan (Jakarta: Rineka Cipta, 2003), 123.

${ }^{6}$ Yudo Wibowo, Penuntun Guru Agama Kristen (Jakarta: BPK Gunung Mulia, 1999), 20.

${ }^{7}$ Muhibbin Syah, Psikologi Pendidikan Suatu: Pendekatan Baru (Bandung: Remaja Rosdakarya, 1995).
}

182 | Copyright $\odot$ 2020, CARAKA, ISSN 2722-1407 (Cetak), 2722-1393 (Online) 
kompetensi yang dimiliki oleh guru pendidikan agama Kristen harus diimplikasikan melalui pembinaan rohani peserta didik Kristen.

Guru pendidikan agama Kristen seyogyanya memberikan ilmu pengetahuan tentang kebenaran Kristus Yesus. Undang-Undang Sistem Pendidikan Nasional Nomor 2 Tahun 1989 pasal 13 ayat 1 a tentang pendidikan agama bahwa setiap peserta didik pada setiap satuan pendidikan berhak mendapatkan pendidikan agama sesuai dengan agama yang dianutnya, dan diajarkan oleh pendidik yang seagama. Pernyataan ini menggambarkan bahwa peserta didik Kristen harus diajarkan oleh guru pendidikan agama Kristen yang seagama dengannya, sehingga kerohaniannya dapat bertumbuh secara baik.

Tercapai tidaknya pembinaan rohani peserta didik Kristen sangat dipengaruhi kompetensi-kompetensi yang dimiliki oleh guru pendidikan agama Kristen. Karena itu, kompetensi-kompetensi yang harus diimplikasikan oleh guru pendidikan agama Kristen adalah kompetensi pedagogik, kepribadian, sosial, profesional, dan spiritual. Teks surat 2 Timotius 2:2 dieksegesis dan hasilnya dideskripsikan, dinarasikan, dan implikasikan bagi kompetensi guru pendidikan agama Kristen dalam membina kerohanian peserta didik Kristen.

\section{METODE PENELITIAN}

Penelitian ini merupakan kajian literatur teks Alkitab menurut 2 Timotius 2:2 yang memuat tentang panggilan Timotius. Metodologi penelitian yang digunakan adalah metodologi penelitian kualitatif, dengan menerapkan tipe metode historikal gramatikal. Historikal gramatikal merupakan metode yang berhubungan dengan tata bahasa dan bagian dari penafsiran Alkitab yang berguna untuk menemukan arti mula-mula sebuah teks. ${ }^{8}$ Tujuan dari metode historikal gramatikal adalah memperoleh pemahaman yang lebih baik mengenai konteks yang memberikan makna. ${ }^{9}$ Pendekatan historikal gramatikal pada penelitian ini dengan mencari makna mula-mula dari teks 2 Timotius 2:2 tentang panggilan Timotius sebagai pelayan Kristus Yesus.

\section{HASIL DAN PEMBAHASAN}

\section{Eksegesis 2 Timotius 2:2}

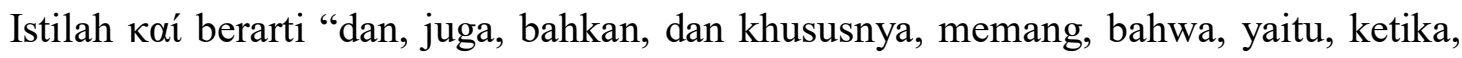
maka, adapun, demikian juga, demikian, sehingga, malah, namun, walaupun, padahal,

${ }^{8}$ Dicky Dominggus, "Kedudukan Kristus Dalam Penciptaan Menurut Kolose 1:15-20 (Tanggapan Kristologi Saksi Yehuwa)," Religi: Jurnal Studi Agama-agama 16, no. 1 (2020): 42-63.

9 Dicky Dominggus, "Makna Dosa Menghujat Roh Kudus," Veritas Lux Mea: Jurnal Teologi dan Pendidikan Kristen 2, no. 1 (2020): 71-79. 
kemudian, lalu, karena, bukan saja...tetapi juga, atau, dari.” Istilah ini di dalam Perjanjian Baru disebutkan sebanyak 9.038 kali. ${ }^{10}$ Makna kata kaí merupakan kata conjunction yang menghubungkan antara induk kalimat dengan anak kalimat maupun bisa digunakan pada awal kalimat. Jadi terjemahan kata kaí yang benar dalam ayat ini adalah kata 'dan.' Ayat 2 ini merupakan kalimat pernyataan bukan pertanyaan. Oleh karena kalimat pernyataan maka kata yang cocok untuk digunakan adalah kata 'dan' bukan 'apa.' Kata yang diikuti ialah yang atau á, ha.

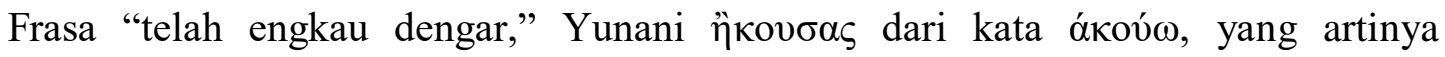
mendengar, mendengarkan; mendengar (dalam pemeriksaan perkara); mengetahui; menaati;

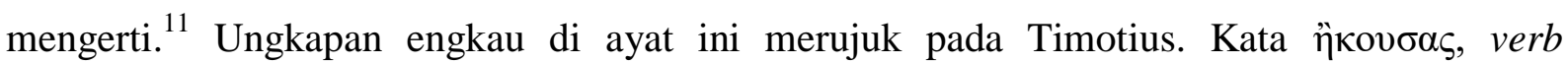
imperative aorist active singular yang artinya bahwa pada waktu dulu Timotius telah aktif mendengarkan perintah yang dinasihatkan oleh berbagai pihak. Namun, di ayat 2 ini kata

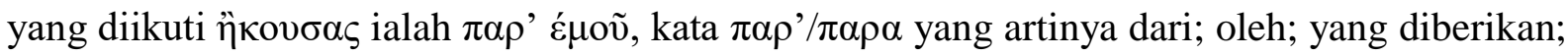
utusan; keluarga; di samping; dekat; rumah; kota; di antara; bersama; dengan; di hadapan; kepada; bagi; menurut; menyusur; di tepi; di pinggir; di; di atas; pada; daripada; lebih dari; melampaui; hampir; karena; melawan; terhadap; bertentangan dengan; kurang. ${ }^{12}$ Kata $\varepsilon$ éõ

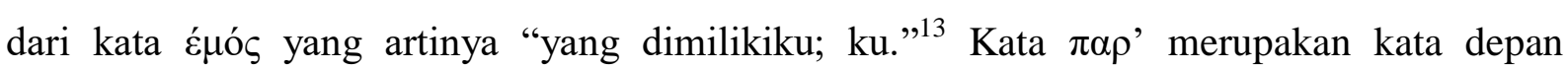

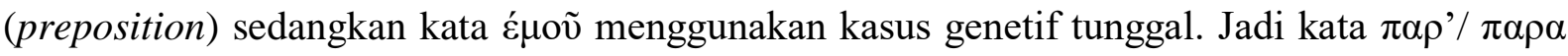
diikuti oleh kasus genetive, maka di ayat 2 ini berarti (datang/berasal); dari Frasa $\pi \alpha \rho ' / \pi \alpha \rho \alpha$

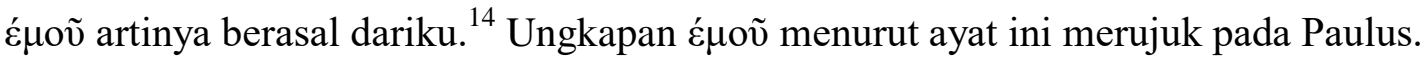

Frasa "di depan banyak saksi," kata di depan dari kata Yunani dió menurut William Hendriksen bahwa The preposition seems to have been derived from the number "two" ( $c f$ “duo and dia). From this it developed into 'be-tween' ('by two's), which, slighty modified in meaning, easly slides into 'among' or 'in the midts of' (and by the different semantic shift, into through'). ${ }^{15}$ Frasa "banyak saksi," dari kata Yunani adalah $\pi 0 \lambda \lambda \omega ́ v ~ \mu \alpha \rho \tau u ́ \rho \omega v . ~ K a t a$ $\pi \circ \lambda \lambda \omega ́ v$ dari kata $\pi$ oגús dalam Perjanjian Baru disebutkan sebanyak 358 kali yang berarti banyak; besar; kuat; hebat; sungguh-sungguh; dengan keras; sangat; nyaring; sering; segera; lama. ${ }^{16}$ Sedangkan kata $\mu \alpha ́ \rho \tau v \varsigma$ yang artinya saksi, martir. ${ }^{17}$ Kata $\mu \alpha \rho \tau v ́ \rho \omega v$, noun genetive plural masculine, yang berarti kata benda dalam kalimat yang berperan sebagai kepemilikan

${ }^{10}$ Hasan Sutanto, Perjanjian Baru Interlinear Yunani-Indonesia Dan Konkordansi Perjanjian Baru (Jakarta: Lembaga Alkitab Indonesia, 2014), 392.

11 Ibid, 34.

12 Ibid, 565.

13 Ibid, 256.

${ }^{14}$ B F Drewes, Kunci Bahasa Yunani Perjanjian Baru (Jakarta: BPK Gunung Mulia, 2013), 38.

15 William Hendriksen, New Testament Commentary (Grand Rapids Michigan: Baker Book House, 1953), 247.

${ }^{16}$ Sutanto, Perjanjian Baru Interlinear Yunani-Indonesia Dan Konkordansi Perjanjian Baru, 618.

${ }^{17}$ Ibid, 472. 
jamak yang bersifat kuat dan teguh. Menurut C. K. Barrett dalam A. T. Hanson menyatakan bahwa "banyak saksi" dimaksudkan untuk memberikan kontras dengan pengajaran gnostik yang rahasia dan esoterik. ${ }^{18}$ Pengajaran yang diajarkan oleh Paulus kepada Timotius tidak berlangsung secara pribadi dan rahasia. Perkataan kepada saksi yang banyak membuktikan bahwa iman rasuli bukanlah semacam tradisi rahasia yang tersembunyi diteruskan kepada orang menurut pengakuan para penganut paham gnostik, sehingga sulit dibuktikan keasliannya. Iman rasuli merupakan sesuatu yang diajarkan di hadapan umum, yang kebenarannya dijamin oleh para saksi yang telah mendengarkannya karena itu dapat mengecek ajaran Timotius sesuai dengan pengajaran yang diajarkan Paulus atau tidak. ${ }^{19}$ Frasa banyak saksi (bdk. 1 Tim. 6:12) dapat berarti para penatua (1 Tim. 4:14) atau para pendengar pengajaran Paulus pada waktu itu yang memberikan kesaksian tentang kebenaran dan juga mengetahui pengajaran yang di dengar oleh Timotius, orang-orang yang hadir pada saat pengangkatan dan pembaptisan Timotius, orang-orang percaya yang telah dibaptis (1 Tim. 4:14; 6:12; 2 Tim. 1:6), dan juga termasuk Barnabas, ibu dan nenek Timotius dan semua orang yang beriman kepada Kristus.

Berdasarkan penjelasan pada klausa di atas, maka dapat diterjemahkan bahwa, Dan yang telah engkau dengar berasal dariku di depan banyak saksi-saksi dan dapat disimpulkan bahwa pada waktu dulu Timotius telah mendengarkan pengajaran benar dari Paulus di depan para saksi termasuk orang percaya di Efesus maupun pengajar gnostik supaya dipercayakan kepada orang-orang yang dapat dipercayai dan orang-orang yang cakap mengajar di jemaat Efesus.

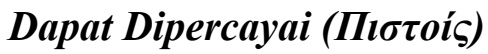

Menarasikan tentang tugas Timotius dalam teks ini sangat jelas. Tugas pertama Timotius yang perlu dilakukan ialah yang dapat dipercayai. Frasa yang mengawali tugas pertama ini ialah "percayakanlah itu kepada orang-orang. Frasa "yang dapat dipercayai dalam bahasa aslinya adalah $\pi \imath \sigma \tau o i ́ \varsigma$.

Kata $\pi \iota \sigma \tau o i \varsigma$ dari kata $\pi \imath \sigma \tau o ́ \varsigma$ yang artinya adalah yang dapat dipercayai; setia; yang percaya; yang beriman; pasti. ${ }^{20}$ Oleh karena kata $\pi l \sigma \tau o i \varsigma$ memakai kasus adjactive dative plural masculine yang artinya kata sifat dalam kalimat yang berperan sebagai objek jamak

${ }^{18}$ A T Hanson, New Century Bible Commentary: The Pastoral Epistles (Grand Rapids Michigan: William Eerdmans Publishing, 1987), 128.

${ }^{19}$ George Arthur Butrick, The Intrepreter's Dictionary of the Bible (Nashville: Abingdon Press, 1962), 478.

${ }^{20}$ Sutanto, Perjanjian Baru Interlinear Yunani-Indonesia Dan Konkordansi Perjanjian Baru, 603. 185 | Copyright@ 2020, CARAKA, ISSN 2722-1407 (Cetak), 2722-1393 (Online) 
dan dari gender yang dipergunakan menunjukkan bahwa kata $\pi \iota \sigma \tau o i \varsigma$ itu berjenis kelamin laki-laki yang diidentikkan dengan kuat, yang gagah perkasa, dahsyat, dan gagah berani.

Kata $\pi \alpha \rho \alpha ́ \theta o v$ dari kata $\pi \alpha \rho \alpha \tau i \theta \eta \mu$ dibaca paratithemi yang artinya menaruh di depan, membentangkan di depan, menyerahkan, membuktikan. ${ }^{21}$ Oleh karena kata $\pi \alpha \rho \alpha ́ \theta o v$ memakai verb imperative 2 Aorist Middle 2 Singular, yang artinya kata kerja dalam kalimat yang mengandung perintah bahwa pada waktu dulu Timotius telah sungguh-sungguh menyerahkan atau mempercayakan tugas pelayanan tidak kepada semua orang tetapi kepada manusia atau orang yang dapat dipercayai untuk melaksanakan tugas pelayanan dimaksud.

Hal ini menunjukkan bahwa rasul Paulus memberi perintah agar Timotius mempercayakan ajaran yang telah diterimanya itu kepada orang-orang yang dapat dipercayai. Kata kerja berbentuk perintah "percayakanlah" dalam bahasa Yunani $\pi \alpha \rho \alpha ́ \theta o v$ berasal dari kata kerja dasar "mempercayakan” (Yun. $\pi \alpha \rho \alpha \tau i \theta \eta \mu l$ ). Kata kerja ini sering dipakai untuk menggambarkan seseorang yang menyimpan uangnya di bank atau seseorang yang menyerahkan barang berharganya kepada orang lain dengan harapan bahwa orang lain itu dapat menjaganya dengan aman. Kata $\pi \alpha \rho \alpha ́ \theta o v$ juga dapat berarti to deposite (menyimpan), to commit (menjalankan), dan entrust (mempercayakan). ${ }^{22}$ Oleh karena istilah $\pi \alpha \rho \alpha \tau i \theta \eta \mu \imath$ di dalam teks ini digunakan kata kerja (verb) berarti mempercayakan. Mempercayakan sesuatu yang berharga kepada seseorang untuk disimpan dengan aman, misalnya menyimpan deposito di bank atau mempercayakan seseorang pada pemeliharaan orang lain.

Timotius sebagai seorang pengajar jemaat tetapi di satu sisi dia harus memilih orang yang tepat untuk diajar, yaitu orang-orang yang dapat memelihara dan menjaga dengan aman "harta yang indah" yang dipercayakan kepadanya. Orang-orang yang tepat di sini disebut sebagai orang-orang yang dapat dipercaya. Kata sifat pistos dipakai di sini dalam arti yang setia. Jadi mereka dapat dipercaya karena mereka setia kepada kebenaran. Tugas yang harus

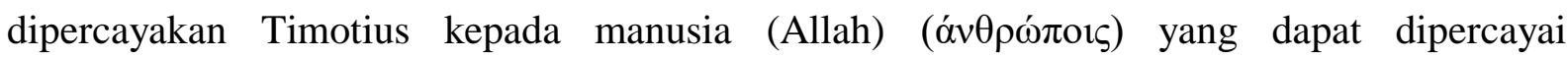
sebagaimana tugas yang dipercayakan rasul Paulus kepada Timotius. Dalam 1 Timotius 1:18 diawali dengan frasa "tugas ini kuberikan kepadamu." R. Budiman menerjemahkan frasa "kuberikan kepadamu" dari bahasa aslinya dengan "kupercayakan kepadamu.,"23 Menurut terjemahan Bahasa Indonesia Sehari-hari (BIS) adalah saya percayakan kepadamu. Frasa ini

${ }^{21}$ Ibid, 573.

${ }^{22}$ Fritz Rienecker, A Linguistic Key to the Greek New Testament (Grand Rapids Michigan: Zondervan Publishing, 1976), 640.

${ }^{23}$ R Budiman, Surat-Surat Pastoral I Dan II Timotius Dan Titus (Jakarta: BPK Gunung Mulia, 1997), 14. 
menarasikan bahwa rasul Paulus hendak berkata kepada Timotius bahwa aku mau mempercayakan pekerjaan ini kepadamu.

Djulius Thomas Bilo menyatakan bahwa tugas yang Timotius terima dari Paulus ini sangat penting. Karena ini nyata dari kata "kupercayakan."24 Karena itu, Timotius harus melanjutkan tugas rasul Paulus yakni memberikan bimbingan spiritual kepada manusia (Allah) atau jemaat-jemaat di Efesus. Apabila dihubungkan dengan 1 Timotius 1:5, maka "Tujuan nasihat itu ialah kasih yang timbul dari hati yang suci, dari hati nurani yang murni dan dari iman yang tulus ikhlas" dalam terjemahan BIS dikatakan bahwa "Tujuan nasihat saya itu adalah supaya orang dapat memiliki hati yang murni dan hati nurani yang suci, serta sungguh-sungguh percaya kepada Tuhan, dan dengan demikian mereka dapat mengasihi sesamanya," maka tugas Timotius mempunyai arti bimbingan spiritual. ${ }^{25}$ Frasa ini disampaikan dengan nada sangat serius oleh rasul Paulus kepada anak rohaninya, Timotius agar dapat dilaksanakan demi membimbing jemaat-jemaat atau manusia Allah.

Berdasarkan penjelasan di atas, maka implementasinya adalah bisa kepada manusia

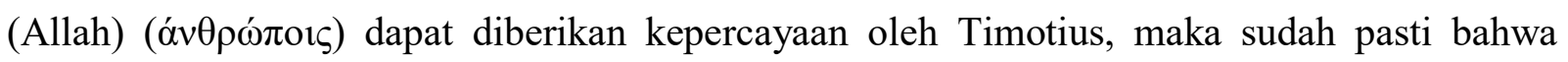
mereka terpanggil untuk mempertanggungjawabkannya. Jadi, tugas yang dipercayakan kepada manusia (Allah) yang sungguh-sungguh setia dan dapat dipercayai.

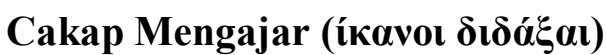

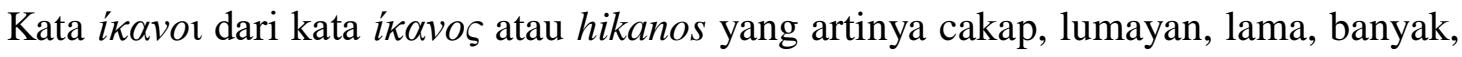
berat, sangat, nyaring, pantas, sanggup, yang menjadi jaminan. ${ }^{26}$ Oleh karena kata ík voo kata sifat nominatif jamak maskulin dan kata ini menduduki deklensi 4 karena berakhiran oi, yang artinya bahwa Timotius perlu mempercayakan tugas kepada orang-orang yang cakap/pandai, yang masih kuat, gagah perkasa, dan berani bertanggung jawab akan panggilannya. Kata ík vor dapat dipahami bahwa seseorang yang dipanggil untuk melayani harus memiliki kompetensi, kesanggupan, kemampuan, atau kecakapan (bdk. 2 Kor 2:17; 3:5-6) khusus dari orang lain yang akan dilayani.

Kata $\delta ı \delta \alpha ́ \xi \alpha \imath$ dari kata $\delta \imath \delta \alpha ́ \sigma \kappa \omega$ yang artinya mengajar, mengajarkan. ${ }^{27}$ Oleh karena kata $\delta 1 \delta a ́ \xi \alpha 1$, memakai kasus verb neutor aorist aktif, maka dapat diartikan bahwa kata kerja dalam kalimat berjenis kelamin netral, yang menunjukkan bahwa pada waktu dulu Timotius telah giat mengajar atau mengajarkan pengajaran sehat. Kata didaxai adalah dalam bentuk

\footnotetext{
${ }^{24}$ Djulius Thomas Bilo, Survive In God (Jakarta: Views, 2016). 25.

${ }^{25}$ Budiman, Surat-Surat Pastoral I Dan II Timotius Dan Titus, 18.

${ }^{26}$ Sutanto, Perjanjian Baru Interlinear Yunani-Indonesia Dan Konkordansi Perjanjian Baru, 370.

${ }^{27}$ Ibid. 192.
} 
aorist 1 infinitive active yang berarti dapat mengajar (to teach), berbicara di depan pertemuan orang banyak dan dapat menegur (to admonish). ${ }^{28}$ Dari pengertian ini rupanya seorang yang cakap mengajar juga harus berani menegur orang yang berbuat yang salah, demi untuk meluruskan kebenaran yang telah diselewengkan. Setiap pengajar selain ia mempunyai bakat mengajar, ia juga harus mempunyai loyalitas yang tinggi terhadap kebenaran. Seseorang yang harus berani membela kebenaran dan selalu mencari kesempatan untuk mentransmisikan kebenaran kepada orang lain.

Jhon R. W. Stott mengatakan bahwa kemampuan yang dicari Timotius pada orang yang kepadanya ajaran yang benar itu diteruskan terdiri sebagian dari integritas atau ketulusan watak dan sebagian lain dari kecakapan mengajar. Mereka harus "didaktikoi" guru yang cakap: kata "didaktikoi" ini dipakai Paulus untuk calon-calon pejabat gereja dalam 1 Timotius 3:2; 2 Tim. 2:24. Pada akhirnya dari ayat ini dapat disimpulkan bahwa tugas Timotius bukanlah tugas yang mudah. Di samping ia harus mengajarkan kebenaran Injil Kristus dengan benar, ia juga harus mengajarkannya kepada orang-orang yang tepat. Dan orang-orang yang menerima pengajaran juga harus dapat mengajarkannya kembali kepada orang lain, dengan demikian 'harta yang indah' itu dapat diteruskan dari generasi ke generasi.

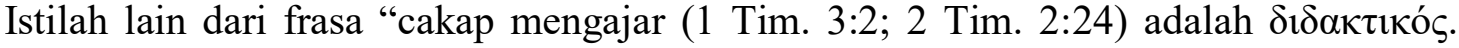
Kata $\delta i \delta \alpha \kappa \tau \iota \kappa o ́ \varsigma$ artinya yang pandai mengajar. ${ }^{29}$ Timotius perlu menentukan orang-orang

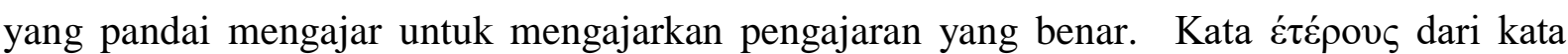

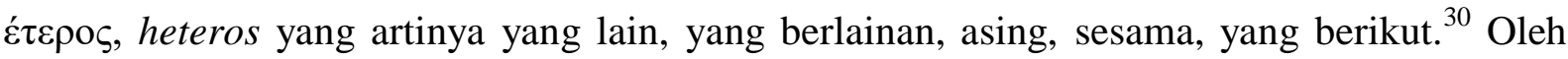

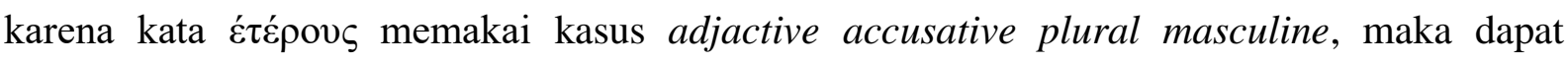
diartikan bahwa kata dalam kalimat yang berperan sebagai objek langsung atau objek

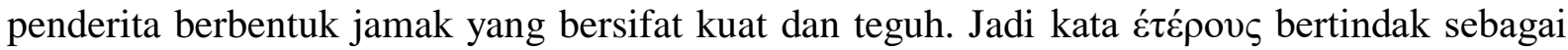
objek langsung atau objek penderita, sehingga Timotius harus mempercayakan tugas kepada orang-orang yang pandai mengajar untuk mengajarkan sesama manusia.

Pemimpin atau pengurus jemaat yang diinginkan Tuhan adalah pemimpin yang cakap mengajar orang lain. Panggilan menjadi pelayan Kristus Yesus untuk membantu Timotius dalam pelayanan pengembalaan sangat diperlukan orang-orang yang cakap mengajar. Karena tanpa memiliki kecakapan dalam mengajarkan pengajaran yang sehat kepada orang lain, maka gereja Tuhan bisa mengalami kehancuran spiritualitas dan moralitas.

${ }^{28}$ Harold K Moulton, The Analytical Greek Lexicon Revised (London: Zondervan Corporation Grand Rapids, 1978), 98.

${ }^{29}$ Sutanto, Perjanjian Baru Interlinear Yunani-Indonesia Dan Konkordansi Perjanjian Baru, 191.

${ }^{30}$ Ibid, 301. 


\section{Kompetensi Guru Pendidikan Agama Kristen}

Kompetensi menunjuk pada suatu kemampuan sebab kompetensi berarti kemampuan atau kecakapan. Dalam melakukan suatu tugas atau pekerjaan sesuai panggilan, maka diperlukan kompetensi. Kompetensi merupakan gambaran hakikat kualitatif dari perilaku seseorang saat menjalankan tugas atau pekerjaan yang dikerjakannya, baik yang ditugaskan oleh orang lain maupun atas inisiatif dari dirinya sendiri untuk dikerjakan. ${ }^{31}$ Mutu dalam bekerja didasarkan pada kecakapan yang dimiliki setiap orang pada semua bidang kerja. Abraham Tefbana menjelaskan bahwa guru pendidikan agama Kristen yang kompeten harus memiliki kecakapan, pemahaman luas, penguasaan terhadap materi dan perilaku yang baik bahkan menjadi teladan yang baik bagi para peserta didik dalam mengajar. ${ }^{32}$

\section{Kompetensi Pedagogik}

Kompetensi pedagogik perlu dimiliki dan dikembangkan oleh seorang calon pendidik atau pendidik dalam mengelola proses pembelajaran. Menguasai ilmu pendidikan atau pengajaran merupakan salah satu syarat penting bagi seorang pengajar untuk mengajar peserta didik Kristen supaya menguasai ilmu pendidikan. Guru pendidikan agama Kristen yang memberikan pengajaran sehat kepada peserta didik disebut pedagog atau ahli pedagogis yang artinya ahli dalam mendidik.

Tholib Kasan dalam bukunya Dasar-Dasar Pendidikan menyatakan bahwa dalam memahami pendidikan perlu diketahui istilah-istilah dalam dunia pendidikan yaitu pedagogi berarti pendidikan dan pedagogia berarti ilmu pendidikan. Istilah pedagogia terdiri atas dua kata yakni paedos dan agoge yang berarti saya membimbing, memimpin anak. Menurut leksikal tersebut, maka seorang pedagogik berarti seseorang yang tugasnya membimbing anak di dalam pertumbuhannya kepada arah berdiri sendiri serta bertanggung jawab. ${ }^{33}$ Membimbing peserta didik ke arah pertumbuhan kerohanian merupakan tugas dan tanggung jawab para pembimbing. Peran seorang pembimbing di dalam lembaga pendidikan formal ialah guru pendidikan agama Kristen.

\section{Kompetensi Kepribadian}

Kompetensi kepribadian perlu dimiliki oleh guru pendidikan agama Kristen saat membina kerohanian peserta didik sebab kompetensi kepribadian yang baik akan berpengaruh

${ }^{31}$ Mau, Integritas Guru Pendidikan Agama Kristen Dalam Membimbing Kepribadian Peserta Didik (Jakarta: Views, 2016), 33.

32 Tefbana, "Korelasi Kompetensi Guru Pendidikan Agama Kristen Dengan Peningkatan Prestasi Belajar Peserta Didik Usia 9-12 Tahun," Luxnos 3, no. 2 (2017): 130.

33 Tholib Khasan, Dasar Pendidikan (Jakarta: Studi Press, 2009), 7. 
positif terhadap perserta didik yang dibina. Djaman Satori, dkk menyatakan bahwa kompetensi kepribadian berkaitan dengan perilaku pribadi guru saat melaksanakan pembinaan kerohanian peserta didik supaya mereka memiliki nilai-nilai luhur yang dapat terpancar di dalam perilaku hidup sehari-hari. ${ }^{34}$ Guru pendidikan agama Kristen sebagai cerminan hidup bagi para peserta didik Kristen dan non-Kristen. Karena itu, guru pendidikan agama Kristen harus menunjukkan sikap, karakter, dan sifat-sifat yang positif dan konstruktif untuk diimitasi oleh seluruh peserta didik di setiap lembaga pendidikan formal. Saat guru pendidikan agama Kristen mengajar tidak hanya dituntut untuk menguasai pengetahuan yang akan diajarkan kepada peserta didik tetapi guru pendidikan agama Kristen sangat perlu menunjukkan sikap perhatian, berpenampilan, dan sikap yang menarik, sikap yang benar dan bertanggung jawab, yang terus-menerus dipertunjukkan kepada peserta didik. ${ }^{35}$

Pada prinsipnya sikap yang benar, sikap yang menarik, dan bertanggung jawab merupakan bagian dari kompetensi kepribadian seorang guru pendidikan agama Kristen dapat diukur dari kapabilitas pengetahuan tentang tatakrama sosial dan kepercayaan yang dimilikinya. Suriani berpendapat bahwa kompetensi kepribadian berkaitan erat dengan perilaku pribadi guru pendidikan agama Kristen yang harus memiliki nilai-nilai rohani yang terpancar dalam perilaku sehari-hari. ${ }^{36}$ Djam'an Satori, dkk berpendapat bahwa kompetensi kepribadian guru mencakup sikap (attitude), nilai-nilai (value), kepribadian (personality) sebagai elemen perilaku (behaviour), dalam kaitannya dengan performance yang ideal sesuai dengan bidang pekerjaan yang dilandasi oleh latar belakang pendidikan, peningkatan kemampuan dan pelatihan, serta legalitas kewenangan mengajar. ${ }^{37}$

\section{Kompetensi Sosial}

Kompetensi sosial adalah suatu kompetensi yang perlu dimiliki oleh guru pendidikan agama Kristen dalam setiap wilayah pengabdiannya, baik di lembaga pendidikan informal, formal, maupun nonformal. Guru pendidikan agama Kristen seharusnya mempuyai kompetensi sosial karena guru pendidikan agama Kristen adalah penceramah zaman modern ini. ${ }^{38}$ Penceramah berarti memberikan ceramah kepada peserta didik di sekolah dan kepada setiap orang di lingkungan masyarakat di zaman ini.

Kompetensi sosial guru pendidikan agama Kristen merupakan kapabilitas untuk berkomunikasi yang baik dengan peserta didik di dalam lembaga pendidikan formal. Tefbana

\footnotetext{
${ }^{34}$ Djaman Satori, Profesi Keguruan (Tangerang: Universitas Terbuka, 2012), 25.

${ }^{35}$ Mau, Integritas Guru Pendidikan Agama Kristen Dalam Membimbing Kepribadian Peserta Didik, 39.

${ }^{36}$ Suriani, "Mengajar Untuk Melipatgandakan Pekerja Kristus," Luxnos 3, no. 1 (2017): 52.

${ }^{37}$ Satori, Profesi Keguruan, 24.

${ }^{38}$ Mau, Integritas Guru Pendidikan Agama Kristen Dalam Membimbing Kepribadian Peserta Didik, 50.
} 190 | Copyright $\odot$ 2020, CARAKA, ISSN 2722-1407 (Cetak), 2722-1393 (Online) 
menuliskan bahwa kompetensi sosial beresensi pada kemampuan seorang guru pendidikan agama Kristen untuk berkomunikasi dengan peserta didik. Karena lewat komunikasi guru pendidikan agama Kristen akan menentukan keberhasilannya dalam interaksi pembelajarannya dengan para peserta didik di sekolah. ${ }^{39}$ Melalui interaksi dalam pembelajaran sehingga guru pendidikan agama Kristen memiliki kesempatan untuk melakukan pembinaan rohani bagi peserta didik Kristen supaya kerohaniannya semakin bertumbuh dengan baik.

Implementasi kompetensi sosial guru pendidikan agama Kristen dalam bersosialisasi dengan seluruh komponen pendidikan termasuk para peserta didik amatlah berpengaruh dengan kualifikasi pendidikan yang dimilikinya. Dewasa ini mulai disadari bahwa kompetensi guru pendidikan agama Kristen sangat diperlukan untuk melaksanakan tugas pembinaan kerohanian di lembaga pendidikan formal. Para guru yang sukses bila dicermati ternyata mereka memiliki kemampuan komunikasi yang baik, berempati, dan pengendalian diri yang menonjol.

\section{Kompetensi Profesional}

Kompetensi profesional adalah kecakapan yang harus dimiliki oleh seseorang dalam melaksanakan suatu pekerjaan secara profesional. Kompetensi profesional pada dasarnya merupakan gambaran yang seharusnya dilakukan seseorang dalam pekerjaannya. ${ }^{40} \mathrm{Jadi}$, guru pendidikan agama Kristen harus memiliki kompetensi profesional dalam menjalankan tugasnya. Guru pendidikan agama Kristen akan semakin profesional dalam melaksanakan pengabdiannya di lembaga pendidikan formal apabila terus-menerus memperlengkapi diri melalui kegiatan webinar, workshop, dan pendidikan profesi. Sebagimana Tefbana mengemukakan:

Seorang guru pendidikan agama Kristen diharapkan secara profesional memberikan dampak dalam pengembangan pendidikan peserta didik. Oleh karena itu, guru pendidikan agama Kristen harus mengikuti pendidikan profesi yang merupakan acuan dalam mengajar dan memperlengkapi diri serta memahami konsep dari profesi yang diikutinya. Selain mengajar, profesionalisme guru pendidikan agama Kristen harus teraplikasi dalam kemampuannya membimbing, mendidik, menanamkan nilai-nilai kehidupan Yesus Kristus kepada peserta didiknya dengan meneladani kehidupanNya. $^{41}$

Guru pendidikan agama Kristen tidak hanya dipanggil sebagai agen untuk mentransferkan ilmu pengetahuan kepada peserta didik di lembaga pendidikan formal, tetapi

\footnotetext{
${ }^{39}$ Tefbana, "Korelasi Kompetensi Guru Pendidikan Agama Kristen Dengan Peningkatan Prestasi Belajar Peserta Didik Usia 9-12 Tahun.”, 133.

${ }^{40}$ Mau, Integritas Guru Pendidikan Agama Kristen Dalam Membimbing Kepribadian Peserta Didik, 55.

${ }^{41}$ Tefbana, "Korelasi Kompetensi Guru Pendidikan Agama Kristen Dengan Peningkatan Prestasi Belajar Peserta Didik Usia 9-12 Tahun.”, 132.
} 
juga menanamkan prinsip-prinsip kebenaran firman Tuhan ke dalam diri peserta didik agar dapat meneladani kehidupan Yesus di dalam kehidupannya sehari-hari.

Standar unjuk kerja guru umum dan guru pendidikan agama Kristen secara khusus telah dituangkan dalam sepuluh kemampuan dasar kerja guru yang dirinci Depdiknas dalam Ahmad Sanusi yang dikutip oleh Marthen Mau adalah sebagai berikut:

(1) Guru dituntut untuk menguasai bahan pengajaran; (2) guru mampu mengelola program belajar dan mengajar; (3) guru mampu mengelola kelas; (4) guru mampu menggunakan media dan sumber pengajaran; (5) guru mampu menguasai landasanlandasan kependidikan; (6) guru mampu mengelola proses belajar mengajar; (7) guru mampu melaksanakan evaluasi pengajaran; (8) guru mampu melaksanakan layanan bimbingan dan penyuluhan; (9) guru mampu membuat administrasi sekolah; (10) guru mampu melaksanakan penelitian tindakan kelas. ${ }^{42}$

Pernyataan kesepuluh standar unjuk kerja ini sudah sepatutnya dimiliki oleh guru pendidikan agama Kristen supaya proses pembelajaran di lembaga pendidikan formal dapat berjalan secara maksimal. Karena itu, guru pendidikan agama Kristen harus mengembangkan diri secara terus-menerus dalam menguasai ilmu pengetahuan dan teknologi agar mampu mentransferkan ilmu pengetahuan secara tepat kepada para peserta didik.

Peraturan Pemerintah Nomor 18 Tahun 2007 menjelaskan bahwa kompetensi profesional seorang guru adalah seperangkat kemampuan yang harus dimiliki oleh seorang guru agar ia dapat melaksanakan tugas mengajar dengan berhasil. ${ }^{43}$ Agar seorang guru pendidikan agama Kristen dapat mengajar dengan berhasil, maka diperlukan memiliki kompetensi/kecakapan profesional. Jadi, guru pendidikan agama Kristen perlu menguasai materi pembelajaran, sehingga cakap untuk mendidik, mengajar, membimbing, dan membina kerohanian peserta didik Kristen secara profesionalisme.

\section{Kompetensi Spiritual}

Pada hakikatnya, keberhasilan seorang guru pendidikan agama Kristen dalam menjalankan tugasnya bukan hanya terletak pada kompetensi pedagogik, kepribadian, sosial, dan profesional tetapi juga pada kompetensi spiritualnya. Kompetensi spiritual guru pendidikan agama Kristen adalah suatu ukuran dalam bentuk penguasaan pengetahuan mengenai kebenaran Tuhan dan perilaku perbuatan agar layak untuk menduduki jabatan fungsionalnya sesuai bidang tugas, kualifikasi, dan jenjang pendidikan. ${ }^{44}$ Spiritual yang dimiliki oleh seorang guru pendidikan agama Kristen bukan terletak pada meditasi di tempat-

\footnotetext{
${ }^{42}$ Mau, Integritas Guru Pendidikan Agama Kristen Dalam Membimbing Kepribadian Peserta Didik, 55.

${ }^{43}$ Hamzah B Uno, Profesi Keguruan (Jakarta: Bumi Aksara, 2011), 18.

${ }^{44}$ Mau, Integritas Guru Pendidikan Agama Kristen Dalam Membimbing Kepribadian Peserta Didik, 65.
} 192 | Copyright $\odot$ 2020, CARAKA, ISSN 2722-1407 (Cetak), 2722-1393 (Online) 
tempat yang salah melainkan pengetahuan kebenaran Tuhan yang harus dimilikinya melalui sumber utama yakni Firman Tuhan.

Kompetensi spiritual adalah kemampuan pendidik untuk mengetahui hal-hal yang bersumber dari Tuhan, yang menjadi bagian hidup dari manusia sebagai bagian dari masyarakat untuk berkomunikasi dan bergaul secara efektif dengan peserta didik, sesama pendidik, tenaga kependidikan, orangtua atau wali peserta didik, dan masyarakat sekitar dengan roh atau jiwa, pikiran dan hati nurani. ${ }^{45}$ Hal senada dikemukakan oleh Tefbana bahwa kompetensi spiritual adalah kemampuan pendidik yang berkaitan dengan hal-hal yang berasal atau bersumber dari Tuhan. ${ }^{46}$

Guru pendidikan agama Kristen bukan hanya memahami arti spiritual tetapi juga harus merealisasikan dalam pengabdiannya. Hal-hal yang berasal atau bersumber dari Tuhan yang telah tertulis di dalam Kitab Suci harus diimplementasikan kepada seluruh peserta didik Kristen di lembaga pendidikan formal. Karena spiritualitas bukan hanya berhubungan dengan hal-hal yang dipercayai tetapi juga berhubungan dengan hal-hal yang dipraktikkan. Guru pendidikan agama Kristen perlu mendidik peserta didik secara baik supaya mereka percaya, menerima, dan beriman kepada Yesus bahkan kerohaniannya semakin berakar, bertumbuh, dan berbuah-buah di dalam Kristus Yesus.

Karena itu, spiritual merupakan cara hidup guru pendidikan agama Kristen yang telah berhasil memahami Kristus Yesus secara utuh. Hal ini dikemukakan mengingat bahwa tugas membina kerohanian bukanlah pekerjaan yang hanya bersifat teknis dan mekanistik. Guru pendidikan agama Kristen merupakan insan yang memiliki aspek spiritual, karena itu perlu diceritakan kepada peserta didik. Untuk itu guru pendidikan agama Kristen semestinya mempercayai dan beriman kepada Tuhan Yesus serta dipraktikkan dalam kehidupan seharihari, mengupayakan pertumbuhan rohani, bertindak dan melayani secara bertanggung jawab. $^{47}$

\section{Implikasinya Bagi Kompetensi Guru Pendidikan Agama Kristen}

\section{Dapat Dipercayai}

Panggilan Timotius sebagai pelayan Kristus menempatkan orang-orang yang terpercaya untuk mendukung pelayanan pekerjaan Tuhan di Efesus. Dalam teks 2 Timotius 2:2 panggilan Timotius yang dapat dipercayai, maka kompetensi yang harus diimplementasikan oleh guru pendidikan agama Kristen dalam teks ini adalah kompetensi kepribadian dan

\footnotetext{
45 Andar Gultom and Saur Hasugian, Profesionalisme, Standar Kompetensi Dan Pengembangan Profesi Guru PAK (Bandung: Bina Media Informasi, 2007), 47.

46 Tefbana, "Korelasi Kompetensi Guru Pendidikan Agama Kristen Dengan Peningkatan Prestasi Belajar Peserta Didik Usia 9-12 Tahun.", 134.

${ }^{47}$ Ibid.
} 
profesional. Kompetensi kepribadian dan profesional yang dimiliki oleh guru pendidikan agama Kristen sangat diperlukan untuk mendidik, mengajar, dan membimbing peserta didik Kristen agar mereka dapat berprestasi di masa yang akan datang. Maria Liakopoulou menegaskan bahwa kompetensi kepribadian dan profesional meliputi sifat-sifat yang berkaitan langsung dengan pelaksanaan tugas sebagai guru adalah komitmen untuk bekerja, rasa percaya diri, bisa dipercayai, dan menghargai orang lain. ${ }^{48}$ Guru pendidikan agama Kristen dapat dipercayai dilihat dari nilai-nilai kejujuran, keadilan, konsistensi, dan selalu memenuhi janji. Sesungguhnya guru pendidikan agama Kristen merupakan pelayan Kristus Yesus yang memeroleh kepercayaan untuk membina kerohanian peserta didik Kristen.

Rasul Paulus menasihatkan kepada Timotius sebagai pelayan Kristus Yesus, ia perlu menyiapkan para pelayan yang lain yang mendapat kepercayaan. Untuk mempercayai seorang pelayan Kristus, maka perlu dilihat dari kesetiaannya dalam mengikuti ajaran yang benar. Guru pendidikan agama Kristen yang dapat dipercayai berarti pribadi yang telah memiliki kompetensi untuk membina kerohanian para peserta didik Kristen agar melaksanakan perintah Yesus Kristus secara benar.

\section{Cakap Mengajar}

Cakap mengajar merupakan bagian dari implementasi kompetensi pedagogik guru pendidikan agama Kristen. Cakap berarti sanggup melakukan sesuatu atau mempunyai kemampuan dan kepandaian untuk mengerjakan sesuatu. Cakap mengajar berarti guru pendidikan agama Kristen mempunyai kesanggupan dan kepandaian untuk mengajar peserta didik. Awaliana Nur Annisa' Rohmawati menyatakan bahwa guru harus mempunyai kemampuan pedagogik dalam mengajarkan dan mendidik peserta didik. ${ }^{49}$ Pernyataan ini dapat dipahami bahwa saat guru pendidikan agama Kristen berbicara dalam mengajar peserta didik Kristen dibutuhkan pedagogik dan perlu memiliki kesabaran dalam mengajarpengetahuan tentang kebenaran Tuhan. Sebagaimana rasul Paulus menasihatkan Timotius bahwaIa harus cakap mengajar, sabar dan dengan lemah lembut dapat menuntun orang yang suka melawan, sebab mungkin Tuhan memberikan kesempatan kepada mereka untuk bertobat dan memimpin mereka sehingga mereka mengenal kebenaran, dan dengan demikian mereka menjadi sadar kembali, karena terlepas dari jerat iblis yang telah mengikat mereka pada kehendaknya ( 2 Tim. 2:24-26).

48 "Guru Profesional Harus Memiliki Kepribadian Yang Baik - Prof. Dr. Dede Rosyada, MA,” accessed August 17, 2020, http://dederosyada.lec.uinjkt.ac.id/reviews/ guruprofesionalharus memilikikepribadian yangbaik.

49 Awaliana Nur and Annisa ' Rohmawati, "Pentingnya Kompetensi Guru Dalam Kegiatan Pembelajaran Di SD (Sekolah Dasar)" (n.d.). 


\section{Memiliki Keberanian Untuk Menegur}

Keberanian untuk menegur peserta didik yang menyeleweng dari ajaran firman Tuhan, kurang disiplin, berbuat salah, kejahatan, dan dosa sangat diperlukan karena sebagai bentuk pertanggungjawaban dalam mengimplementasikan kompetensi sosial. Sebagaimana rasul Paulus menasihatkan kepada Timotius bahwa, "Mereka yang berbuat dosa hendaklah kautegor di depan semua orang agar yang lain itu pun takut (1 Tim. 5:20). Yesus juga mengajarkan kita untuk menegur di bawah empat mata, teguran yang dilandasi oleh asas saling percaya dan kasih. Oleh sebab itu, menegur, memperbaiki, mengajak kembali peserta didik yang melakukan kesalahan selalu diletakkan dalam kerangka menerima kembali peserta didik dalam kasih Kristus.

Sumber utama yang perlu dipakai untuk menegur peserta didik adalah Firman Tuhan. Sebagaimana rasul Paulus menuliskan bahwa, "Segala tulisan yang diilhamkan Allah memang bermanfaat untuk mengajar, untuk menyatakan kesalahan, untuk memperbaiki kelakuan dan untuk mendidik orang dalam kebenaran (2 Tim. 3:16).

\section{Memiliki Kesetiaan}

Kesetiaan guru pendidikan agama Kristen dalam pelayanan sangat diperlukan. Karena itu, kepercayaan yang diberikan Allah mesti dilaksanakan secara loyal dalam mengabarkan dan mengajarkan firman Tuhan atau kebenaran Alkitab kepada orang percaya atau peserta didik. ${ }^{50}$ Kesetiaan guru pendidikan agama Kristen dalam memberikan pengajaran merupakan salah satu unsur kompetensi yang perlu ditumbuhkembangkan oleh guru pendidikan agama Kristen dalam pengajarannya.

Agar kesetiaan guru pendidikan agama Kristen semakin nampak dalam setiap pengajarannya, maka ia perlu beriman sungguh-sungguh kepada Tuhan Yesus Kristus. Iman kepada Yesus Kristus merupakan inti keberhasilan seorang guru pendidikan agama Kristen dalam menjalankan panggilannya sekaligus mengimplementasikan kompetensi-kompetensi dalam membina kerohanian peserta didik supaya mereka semakin loyalitas dalam Tuhan Yesus Kristus. Namun yang perlu diekspresikan oleh guru pendidikan agama Kristen adalah iman yang timbul dari dalam hati yang paling dalam. ${ }^{51}$

\footnotetext{
${ }^{50}$ Peter Wongso, Teologi Penggembalaan (Malang: Seminari Alkitab Asia Tenggara, 1991), 10.

${ }^{51}$ Martin and Deidre Bogban, Bimbingan Berdasarkan Firman Allah (Bandung: Yayasan Kalam Hidup,
} 1985), 201 


\section{Memiliki Integritas}

Teks di dalam 2 Timotius 2:2 para pelayan Kristus Yesus yang dipercayakan Timotius untuk pelayanan perlu memiliki integritas yang baik. Integritas berarti dapat dipercaya, jujur, dan setia. ${ }^{52}$ Unsur integritas hubungan erat dengan kompetensi kepribadian. Karena itu, guru pendidikan agama Kristen harus mengimplementasikan kompetensi kepribadian tentang memiliki integritas karena integritas adalah modal yang dimilikinya untuk mendidik, mengajar, dan membina para peserta didik supaya memiliki integritas yang semakin baik pula.

Rohani mempunyai ukuran penting untuk ditanamkan di dalam diri para peserta didik Kristen sejak pada masa dini agar mereka tidak mudah dipengaruhi oleh kehidupan yang membahayakan dirinya, misalnya belajar untuk mengonsumsi narkoba, minuman keras, seks bebas, dan lain-lain. Peserta didik Kristen yang telah memiliki integritas yang baik sebagai pertanda bahwa mereka telah memiliki kerohanian dan moral yang baik karena bukan guru pendidikan agama Kristen saja yang dituntut untuk berkompetensi spiritual tetapi peserta didik juga sangat dituntut memiliki berbagai kompetensi, termasuk kompetensi kerohanian.

\section{Kualitas Kerohanian}

Pada hakikatnya peserta didik Kristen mampu memiliki kualitas kerohanian, karena itu guru pendidikan agama Kristen perlu membina mereka. Salah seorang peserta didik Kristen berpendapat bahwa mereka dibina oleh guru pendidikan agama Kristen untuk memiliki kualitas kerohanian dalam hal mengasihi Yesus Kristus dengan segenap hatinya, bahkan mereka juga dibina supaya mengasihi orangtua dan sesama manusia. Dalam membina kerohanian peserta didik Kristen, maka guru pendidikan agama Kristen perlu memiliki standar kualitas tertentu yang mencakup tanggung jawab, wibawa, mandiri, dan disiplin. Hal ini mengindikasikan bahwa guru pendidikan agama Kristen yang memiliki kualitas kerohanian yang mantap dalam melakukan pembinaan terhadap peserta didik Kristen akan berpengaruh besar pada kualitas kerohanian mereka.

Sebenarnya memiliki kualitas kerohanian bukan suatu hal yang sulit, tetapi kadang sebagian orang tidak menginginkan untuk memilikinya karena dianggap bukan hal yang penting. Peserta didik Kristen di lembaga pendidikan formal belum memiliki kualitas kerohanian karena adanya pengaruh lingkungan keluarga dalam membina peserta didik Kristen dari segi kerohanian. Sedangkan sebagian peserta didik Kristen sudah memiliki tingkat kualitas kerohanian. Sebagai contoh saat disuruh bernyanyi dan berdoa sudah bisa dilaksanakan dengan baik. Timbulnya kerohanian peserta didik Kristen disebabkan oleh

${ }^{52}$ Mau, Integritas Guru Pendidikan Agama Kristen Dalam Membimbing Kepribadian Peserta Didik, 126. 
karena dorongan dari para guru pendidikan agama Kristen yang terus-menerus dilakukan dan bukan merupakan warisan paten dari orang tua atau keluarga. Dorongan tersebut dilakukan oleh karena merupakan tuntutan dalam Firman Tuhan yang sesuai dengan ajaran Tuhan Yesus Kristus.

\section{KESIMPULAN}

Timotius menerima panggilan pelayanan di jemaat Efesus oleh karena dapat dipercayai oleh Kristus Yesus melalui rasul Paulus. Rasul Paulus menugaskan untuk mempercayakan orang-orang yang terpercaya dan mempercayakan orang-orang yang cakap mengajar di Efesus untuk membantu pelayanan pengembalaan. Hasil eksegesis teks surat 2 Timotius 2:2, maka dapat diketahui bahwa guru pendidikan agama Kristen mendapat panggilan dari Tuhan untuk mengimplikasikan kompetensinya. Karena itu, secara teori dan praktik kompetensi yang harus dimiliki oleh guru pendidikan agama Kristen yakni kompetensi pedagogik, kepribadian, sosial, profesional, dan spiritual. Proses pembinaan rohani peserta didik Kristen bisa berlangsung dengan baik apabila guru pendidikan agama Kristen memiliki kompetensi-kompetensi dimaksud. Selain daripada itu, guru pendidikan agama Kristen dapat dipercayai, cakap mengajar, berani untuk menegur yang salah, memiliki kesetiaan, memiliki integritas, dan memiliki kualitas rohani. Dengan demikian, semakin guru pendidikan agama Kristen mengimplikasikan kompetensinya dalam pembinaan rohani peserta didik Kristen, maka rohani peserta didik Kristen akan semakin baik.

\section{DAFTAR PUSTAKA}

Bilo, Djulius Thomas. Survive In God. Jakarta: Views, 2016.

Budiman, R. Surat-Surat Pastoral I Dan II Timotius Dan Titus. Jakarta: BPK Gunung Mulia, 1997.

Butrick, George Arthur. The Intrepreter's Dictionary of the Bible. Nashville: Abingdon Press, 1962.

Dominggus, Dicky. "Kedudukan Kristus Dalam Penciptaan Menurut Kolose 1:15-20 (Tanggapan Kristologi Saksi Yehuwa).” Religi: Jurnal Studi Agama-agama 16, no. 1 (2020): 42-63.

. "Makna Dosa Menghujat Roh Kudus." Veritas Lux Mea: Jurnal Teologi dan

Pendidikan Kristen 2, no. 1 (2020): 71-79.

Drewes, B F. Kunci Bahasa Yunani Perjanjian Baru. Jakarta: BPK Gunung Mulia, 2013.

Firdaus, Firdaus. "Upaya Pembinaan Rohani Dan Mental." Al-Adyan: Jurnal Studi Lintas Agama 9, no. 1 (2014): 119-142.

Gultom, Andar, and Saur Hasugian. Profesionalisme, Standar Kompetensi Dan Pengembangan Profesi Guru PAK. Bandung: Bina Media Informasi, 2007.

Hanson, A T. New Century Bible Commentary: The Pastoral Epistles. Grand Rapids Michigan: William Eerdmans Publishing, 1987.

Hendriksen, William. New Testament Commentary. Grand Rapids Michigan: Baker Book House, 1953. 
Ihsan, H Fuad. Dasar-Dasar Kependidikan. Jakarta: Rineka Cipta, 2003.

Khasan, Tholib. Dasar Pendidikan. Jakarta: Studi Press, 2009.

Kurniadi, Trisno. "Penguasaan Diri Hamba Tuhan Dalam Pelayanan Kajian Eksegetikal 2 Timotius 4:1-8." Manna Rafflesia 3, no. 2 (2017): 131-156.

Martin, and Deidre Bogban. Bimbingan Berdasarkan Firman Allah. Bandung: Yayasan Kalam Hidup, 1985.

Mau, Marthen. Integritas Guru Pendidikan Agama Kristen Dalam Membimbing Kepribadian Peserta Didik. Jakarta: Views, 2016.

Moulton, Harold K. The Analytical Greek Lexicon Revised. London: Zondervan Corporation Grand Rapids, 1978.

Nur, Awaliana, and Annisa ' Rohmawati. "Pentingnya Kompetensi Guru Dalam Kegiatan Pembelajaran Di SD (Sekolah Dasar)" (n.d.).

Rienecker, Fritz. A Linguistic Key to the Greek New Testament. Grand Rapids Michigan: Zondervan Publishing, 1976.

Rukku, Maria, and Daniel Ronda. "Pemimpin Yang Memiliki Integritas Menurut 2 Timotius Pasal 2." Jurnal Jaffray 9, no. 1 (2011): 25.

Satori, Djaman. Profesi Keguruan. Tangerang: Universitas Terbuka, 2012.

Stott, John R W. 2 Timotius. Jakarta: Yayasan Bina Kasih OMF, 1997.

Suriani. "Mengajar Untuk Melipatgandakan Pekerja Kristus.” Luxnos 3, no. 1 (2017): 52.

Sutanto, Hasan. Perjanjian Baru Interlinear Yunani-Indonesia Dan Konkordansi Perjanjian Baru. Jakarta: Lembaga Alkitab Indonesia, 2014.

Syah, Muhibbin. Psikologi Pendidikan Suatu: Pendekatan Baru. Bandung: Remaja Rosdakarya, 1995.

Tefbana, Abraham. "Korelasi Kompetensi Guru Pendidikan Agama Kristen Dengan

Peningkatan Prestasi Belajar Peserta Didik Usia 9-12 Tahun." Luxnos 3, no. 2 (2017): 130.

Uno, Hamzah B. Profesi Keguruan. Jakarta: Bumi Aksara, 2011.

Wibowo, Yudo. Penuntun Guru Agama Kristen. Jakarta: BPK Gunung Mulia, 1999.

Wongso, Peter. Teologi Penggembalaan. Malang: Seminari Alkitab Asia Tenggara, 1991. "Guru Profesional Harus Memiliki Kepribadian Yang Baik - Prof. Dr. Dede Rosyada, MA.” Accessed August 17, 2020. http://dederosyada.lec.uinjkt.ac.id/ reviews/guruprofesional harusmemilikikepribadianyangbaik. 